\title{
Reseña
}

\section{Mario Oliva Medina: 1 de Mayo en C. R. 1913-1986}

(Heredia: SITUN, 2013, 125 páginas)

$\mathbf{E}$ 1 primero de mayo se erige como una fecha conmemorativa internacional basda, simbólicamente, en el recuerdo de los "mártires de Chicago" (EU, 1886) y en la decisión del Congreso Obrero Socialista de la Segunda Internacional (París, 1889). Una celebración nacida de la lucha obrera no llegó a Costa Rica hasta 1913 y se le relaciona, directamente, con el desarrollo del movimiento, de las conquistas, de las luchas y de su futuro en este país. Su historia está asociada a destacadas figuras de la intelectualidad de la primera mitad del siglo XX y la instauración del Código de Trabajo en 1940 representa un hito en el devenir histórico del movimiento de la clase trabajadora en Costa Rica.

El estudio de Oliva, desde su visión de historiador, se sitúa primeramente en las celebraciones que van del año 1913 a 1932 y sus vaivenes: quiénes las celebraron y en qué años no lo hicieron, así como el contenido temático de cada una y el tipo de actos llevados a cabo (discursos, conferencias, siembra de un árbol, desfiles, publicaciones).
La segunda parte de la obra abarca el corto periodo de 1933 a 1940, años en que se consolida la celebración del día del trabajador y la influencia del Partido Comunista en este hecho, donde destacan importantes figuras de esta joven agrupación política. El periodo Trabajo, órgano oficial del Partido, da cuenta de los actores en los distintos lugares del país. La consigna había cambiado: más que la recordación de los mártires de Chicago y la jornada de ocho horas, se trataba de luchar y de vencer el capitalismo, además de otros temas que preocupaban entonces: el internacionalismo proletario, la guerra, la explotación obrera.

La tercera parte está dedicada a los ocho años de 1940-1948 cuando se da la alianza entre el Partido Comunista y el Republicano Nacional, que arranca con el gobierno del Dr. Rafael Ángel Calderón Guardia (1940-1944) y el de Teodoro Picado Michalski (1944-1948) y surge la guerra civil de 1948, la cual llevó a la prisión a dirigentes del comunismo. 
El largo periodo de 1949 a 1968, analizando en la cuarta sección del estudio de Oliva, es calificado por este autor como un ciclo difícil que se caracteriza por el reflejo, la represión oficial y patronal, y la división de la agrupación política de izquierda. La represión se expresa en la violencia, la persecución, el exilio y la censura. Estas acciones influyeron en la conmemoración del día del trabajador y marcaron un antes y un después en su historia.

El quinto apartado muestra un giro favorable al movimiento de la clase trabajadora correspondiente al decenio 1969-1979. Es el periodo de auge al fortalecerse los sindicatos tanto en el sector agrícola como en el industrial y de servicios, marcados por el aumento de trabajadores (as) en organizaciones y su combatividad o espíritu de lucha, todo en el contexto social del crecimiento del proletariado. En este marco se da la conocida lucha contra ALCOA, donde la participación estudiantil fue fundamental.
El declive del primero de mayo, como lo denomina Mario Oliva, identifica el último periodo en estudio (1980-1986): el movimiento obrero se muestra debilitado ante la crisis de los ochenta, las desafiliaciones y el auge del solidarismo.

Concluye el autor que cada ciclo analizado se caracteriza por las diversas maneras en que se asumió la conmemoración en Costa Rica, lo cual nos permite hacer una revisión histórica de su desarrollo, vicisitudes, importancia y vigencia. Este estudio, por lo tanto, viene a llenar el vacío existente en la historiografía costarricense en relación con este tema y constituye un aporte básico para el conocimiento del "día del trabajo" y su conmemoración en nuestro país. 